\title{
LINGUISTIC THOUGHTS AS THE BASIS OF ARABIC LEARNING INNOVATION
}

\author{
Thontowi \\ University of Ahmad Dahlan Yogyakarta, Indonesia \\ Corresponding E-mail: thonthowi.uad@gmail.com
}

\begin{abstract}
This study aims to discuss linguistic thoughts and Arabic learning in Indonesia, along with both innovation opportunities and their actualization in the development of Arabic learning. This study is literary with an intertextual approach to the literature associated with two fields. The meaning of the text is done by content analysis. This study concludes that the innovation of linguistic thoughts and Arabic learning can be done on three levels, namely Arabic linguistic study and development, contextualization of Arabic research methodology, and standardization of ICT-based Arabic language learning and research. Various problems surrounding learning Arabic language can be solved through research and study of Arabic linguistics in depth, comprehensive and cross-disciplinary of science. Opportunities to innovate linguistic thoughts and language learning are wide open. Various scientific forums and journals as well as research in Arabic-based learning development of linguistic thought can lead to tajdîd (reform, innovation) and ijtihâdat lughawiyyah (linguistics innovation). The future of linguistic studies and Arabic learning in Indonesia is believed to be very bright and enlightening if reinforced by the development of linguistic research meth-ods and Arabic learning.
\end{abstract}

Keywords : Innovation, linguistic thought, Arabic learning, linguistic research, scientific and academic forums

\section{Introduction}

Arabic is the one and only language in the world that received a great attention throughout its history because it is related to the holy book (Al-Quran) and the religion of Islam. One of the factors that caused such attention is because the main source of Holy Book of Islam (Al-Qur'an) is Arabic ${ }^{1}$. Such a large and multidimensional concern, so the text of AlQur'an is studied from various perspectives and disciplines, ranging from: the science of recitation, the science of qira'at (the readings), ulum (science) of the Qur'an, interpretation and other Islamic science. All scientific studies that pivot to the Al-Qur'an can be ascertained through Arabic. The process of theorizing and codification of traditional sciences (al-'ulûm alnaqliyyah), such as: fiqh (Islamic jurisprudence), ushul fiqh (principles of fiqh), kalam (Islamic theology), Sufism, 'ulum al-Qur'an,' ulûm al-hadîts, 'ilm al -akhlâq, and others must use Arabic as a media for Islamic studies, Due to the main source and reference is the Al-Qur'an

\footnotetext{
${ }^{1}$ Tammâm Hassân, al-Fikr al-Lughawî al-Jadîd, (Kairo: 'Alam al-Ma’rifah, 2011),Vol.1 p. 9
} 
Therefore, In the history of Islamic civilization, Arabic has a very significant role in developing various sciences, especially Islamic sciences ${ }^{2}$. But the scientific study of Arabic experienced "up and down" in the trajectory of the history of the Arabic sciences. During the Umayyad period, especially in the reign of Abdul Malik bin Marwan (646-705 AD), the fifth Caliph of the Umayyad caliphate had pioneered the Arabization movement (harakat at-ta'rîb) in the field of government administration. The language of administration, communication, and socio-economic transactions at that time used Arabic. During the Abbasid Caliphate there was a translation movement (harakat at-tarjamah wa an-naql) and the development of Islamic sciences and science. It was during the golden age of Islamic civilization, and the study of language grew rapidly.

Many 'ulama (Islamic theologician) and works of language, including linguistics, that were born and adorned the development of science at that time ${ }^{3}$. Arabic is also adorned the life of Islam in Andalusia, through the characteristic architecture of ornaments on the walls of the building. Arabic calligraphy inscriptions (muqarnas) are written in every mosque, palace, house in the Andalusian region as found in the Alhambra fortress, Granada, which is filled with Islamic inscriptions from Arabic poetry and Al-Qur'an'.

After the golden age of Islamic civilization has elapsed, the Islamic world suffered a setback, not only in the socio-economic and political fields, but also in the intellectual and academic fields. The West rose (aufklarung, renaissance) and took over the "Islamic world" by carrying out colonization and realization. The Islamic denomination is getting worse with the shattered of Islamic world. The Arabic studies also declined and were stagnant. Some language works are formulated in the form of "nazhaman" (concise) as the learning material to be memorized (and be understood).

The books are in the form of verses of poetry which is well-known as Kitab Kuning (alKutub as-Shafra ') in Islamic boarding schools in Indonesia such as: al-Imrithi, al-Ajurumiyyah, Alfiyah, Jawhir al-Maknn and Uqd al-Jumara become the main references of Arabic studies in most Islamic boarding schools in Indonesia. Except in modern Islamic boarding schools (ma'had ashrî) such as Modern Boarding School Darussalam Gontor and so on, Muhammadiyah boarding schools and other modern boarding schools that are affiliated with PKS (Partai Keadilan Sejahtera, 'One of Party in Indonesia'). And those books and others in the fields of aqeedah, fiqh, tasawuf, Islamic history, and others until now are still used, even in the last decades that is contested by the Indonesian Ministry of Religion, with the name Musâbaqah Qirâ'at al-Kutub (MQK).

There are several arguments of why linguistic thoughts and Arabic learning in Indonesia need to be innovated. First, two disciplines (linguistics and Arabic language learning) are basically always able to be updated by developing the research methodology and development. Ijtihad (diligence) of linguistic thoughts and Arabic learning field have never been closed. Before reformulating the meaning and mabna of Arabic in its monumental book, al-'Arabiyyah Ma'hâha Mabnâhâ (1973), Tammam Hassan formerly established his "innovation project" of Arabic linguistic thoughts by formulating the Manahij al-Bahts fi

\footnotetext{
${ }^{2}$ Muhbib Abdul Wahab, "Peran Bahasa Arab dalam Pengembangan Ilmu dan Peradaban Islam", in Arabiyat: Jurnal Pendidikan Bahasa Arab dan Kebahasaaraban, Vol. I, No. 1, June 2014, p. 1-20.

${ }^{3}$ Look up at 'Abduh al-Hilwu dan Bahzad Jabir, al-Wafi fi Târîkh al-'Ulûm 'inda al-'Arab, (Beirut: Dar alFikr al-Lubnani, tt), p. 20-35

${ }^{4}$ Jose Miguel Puerta Vilchez, Reading the Alhambra: A Visual Guide to the Alhambra through its inscripstion, (Granada: The Alhambra and Generalife Trust, 2010), p. 15
} 
Lughah (Language Research Methodology, 1955)5. In other words, It is significant if innovation in linguistic thoughts and Arabic language learning based on a clear and systematic foundation of research methodology. Thus, the scientific outcome that produced is more robust and mature.

Second, contemporary issues and problems in the field of Arabic learning in Indonesia nowadays need to be solved by utilizing the disciplines that are currently developing rapidly, such as: neurology, pragmatics, textology, computational linguistics, including theories of multiple intelligences, contextual theory, generative-transformative theory, constructivism theory, and so on. For example, the problem of the low interest and motivation to learn Arabic is not merely a psychological problem, the learner are lethargic in learning Arabic. This problems are quite complex, it is not only related to psychological problems, but also related to teaching materials, approaches and methods of educators in teaching Arabic, media and learning environment etc., thus, that the solution must be comprehensive and integrative ${ }^{6}$.

Third, the opportunities for doing an effort towards linguistic still existed, because basically linguistic of Arabic is a dynamic science and still developing as the progress of the time. Tammam Hassan is one of the proof, he writes a masterpiece that can be an inspiration to stir up ijtihad (diligence) in the field of linguistic thoughts ${ }^{7}$. This discipline is not much developed yet in Islamic universities in Indonesia. Arabic language experts still tend to focus on "Arabic content" as teaching material. In other words, some Arabic language experts in Indonesia are still 'market oriented' in creating their works, instead of oriented to scientific development.

This paper aims to discuss and develop the importance of innovation ${ }^{8}$ in Arabic linguistic thoughts - in this case we have an abundance of linguistic thoughts that is bountifuland innovation in Arabic research methodology, then innovation in Arabic learning. These three aspects are inseparable. The final aim of this paper is to invite all of us to look back the scientific construction of Arabic language learning integratively with the methodology of language research (in education) that is being an instrument in the science development and Arabic linguistic thought as its "theoretical foundation". The thesis emphasized that Arabic learning in Indonesia needs to be developed based on research that is comprehensive and supported by innovation and the development of linguistic studies combined with various interdisciplinary developments.

\footnotetext{
${ }^{5}$ Muhbib Abdul Wahab, Pemikiran Linguistik Tammâm Hassân dalam Pembelajaran Bahasa Arab, (Jakarta : UIN Press, 2009), p. 89-91

${ }^{6}$ Look up Alan Clark, "Nahwa Uslûb Jadîd fi Ta'lîm al-Lughah al-‘Arabiyyah”, in Sa'id bin Ali al-Qahthani. A'mâl Mu'tamar Ittijâhat Hadîtsah fi Ta'lîm al-Lughah al-'Arabiyyah Lughah Tsâniyah, Riyadh: Jâmi'ah al-Malik Sa'ud, February 10-12, 2014, p. 14

${ }^{7}$ Read Hassân, Ijtihâdât Lughawiyyah, (Kairo: 'Âlam al-Kutub, 2007).

${ }^{8}$ About the meaning of innovation, look Victoria Neufeldt et.al. Webster's New World Dictionary, (New York: Simon \&Schuster Inc., 1988), p. 696 and Ahmad SH. Al-Khatib, Mu'jam al-Mushthalahât al-'Ilmiyyah wa al-Fanniyah wa al-Handasiyyah, (Beirut: Maktabah Lubnan, 1991), Vol. VI, p. 304.
} 


\section{Result and Discussion}

\section{A. The history of Development Arabic Linguistic Thoughts}

Arabic linguistic studies in this country that are relatively undeveloped as in some Middle Eastern countries such as Egypt, Saudi Arabia, Morocco, and Jordan. It needs more consideration from experts and practitioners of Arabic language education. The need to learn and master Arabic in Indonesia is still practical-pragmatic and all it mostly tends to be religious oriented ${ }^{9}$. And it has not oriented yet towards Arab linguistic studies seriously. Even though the works of Arabic linguistics are relatively developed and are often found, and it makes easier for us to adapt and develop Arabic linguistic thoughts in Indonesia. However, this fact can be understood because the establishment and development of the Arabic Language Education Study Program and the Arabic Language and Literature Study Program in Indonesian universities have only begun to organize and develop their new curriculum and scientific structure in the 2000s.

Arabic linguists had inherited many monumental works of linguistics that is interesting to be reviewed and contextualized with the development of the era. Ibn Jinni with his al-Khashâish, as-Sakkaki with his Miftâh al-Ulûm, to as-Suyuthi with his al-Muzhir fi Ulûm al-Lughah. The study in these books is basically alluring and profound than the work of Ferdinand de Saussure, JR. Firth, Skinner, even Noam Chomsky and Charles Morris. Therefore, the process of adaptation and modification of linguistic thoughts in the modern era also took place, for example, with the publication of the book - Nazhariyyat al-Lughawiyyah wa-Nafsiyyah wa Ta'lîm al-Lughah al'Arabiyyah (1420 H) by 'Abdul Aziz ibn Ibrahim al-Ushaili.

One of study field which is the development of linguistics is language pragmatics (at-tadâwuliyyah). This field examines language in its use or in communicative interactions. In addition, pragmatics examines the context aspects of the structure of language in order to reveal the meaning and the intention of the speaker ${ }^{10}$. This study became interesting and important to be innovated and even included in the structure of the Arabic or Arabic literature education curriculum because when we take a look about the use of language, it is not possible to understand the message well if we do not understand the purpose of the language user properly. Even in several state universities under the Ministry of Education and Culture, pragmatic teaching has become a separate subject. Among the books that became the reference is "Pengajaran Pragmatik" (Pragmatic Teaching) by Henry Guntur Tarigan"1. Learning Arabic in various educational institutions has also not yet arrived at learning and developing discourse. In general, the learning orientation of Arabic in Indonesia is still focused on Fahm al-Maqrû (Understanding), especially reading socio-religious texts.

9 Ahmad SH. Al-Khatib, Epistemologi dan Metodologi Pembelajaran Bahasa Arab, (Jakarta: Lembaga Penelitian UIN Jakarta Pers, 2008), p. 105-106.

${ }^{10}$ Mahmud Ahmad Nahlah, Âfâq Jadîdah fi al-Bahts al-Lughawî, (Alexandria: Dâr al-Ma'rifah al-Jami'iyyah, 2002), p. 12-14.

${ }^{11}$ Read Henry Guntur Tarigan, Pengajaran Pragmatik, (Bandung: Angkasa, 2009). 
The innovation of Arabic linguistic thoughts in Indonesia is very significant to be implemented for several reasons. First, Arabic linguistics is the basis for curriculum and scientific development in Arabic generally. Second, the appearance of Arabic Language Education Study Programs (PBA) and Arabic Language and Literature (BSA) enables that Arabic linguistic thoughts is spreading. Third, research and writing of books on Arabic linguistics in Indonesia have begun to emerge. For example, "Cakrawala Linguistik Arab" (Arabic Linguistic Horizon) (2013) by Moh. Syarif Hidayatullah, "Semantik Bahasa Arab" (Semantic of Arabic Language) (2008) by Moh. Ainin and Imam Asrori, Psikolinguistik: Kajian Teori dan Aplikasi (Psycholinguistics: Theory and Application Studies) (2014) by Agus Tricahyo, and so on. Fourth, scientific journals that can accommodate and develop linguistic thoughts in Indonesia have also begun to emerge, such as Arabiyat Journal (FITK UIN Jakarta), Lingua and al-Lisan al'Arabi (UIN Maliki), Lisania (IAIN Salatiga), and so on. Fifth, various scientific forums (seminars, conferences and discussions) about Arabic are increasingly evolved, such as the forum PINBA (Arabic Scientific Week) organized by IMLA (Ittihad Mudarrisî alLughah al-'Arabiyyah) national and international seminars by ADIA (Association of Adab Lecturers), and Arabic Language Education Study Programs (PBA) and Arabic Language and Literature (BSA).

The innovation of Arabic linguistic thoughts can be done by remapping the various linguistic problems that exist and responding to contemporary issues about Arabic language at the same time. Some of these problems, among others, the problem of the relations between ma'na (meaning) and mabna, the significance of Arabic texts, standardization of the Arabic-Indonesian dictionary and otherwise, and so on. Whereas the contemporary issues need to be responded to and developed, for example the issue of language politics, the economy of Arabic, Arabic culture, Arabic in social media, Arabizi phenomena (Arab-Inklizi), the phenomenon of ta'rîb wa tawlîd, and so on. Everything requires rethinking and innovation through earnerst, in-depth, and comprehensive research.

\section{B. The Significance of Arabic Linguistic Thoughts Innovation}

The Arabic language research methodology has not got some consideration yet from Arabic reviewers, even though research methodology is an instrument (tool) and a means for the development of the Arabic knowledge. Without a sophisticated research methodology, undoubtedly the innovation and renewal of the knowledge of language will not exist. In other words, without the support of the development of research methodology, the language sciences tend to stagnate.

According to the author's observation, the book of research methodology of Arabic language in Indonesia is still not widely publicized yet. Metodologi Penelitian untuk Pengajaran Bahasa Asing ( Research Methodology for Teaching Foreign Languages) (2006) by Ag. Bambang Setiyadi, Metodologi Penelitian Bahasa Arab (Research Methodology of Arabic Language) (2007) by Moh. Ainin, and the Metodologi Penelitian Bahasa ( Language Research Methodology) (2007) by Abdul Halim Hanafi are some examples that have been published. And similar books in the Arab world are very abundant, for example Manahij al-Bahts fi al-Lughah wa al-Mu'jam (1991) by 
Abdul Ghaffar Hami Hilal, Mabahits fi 'Ilm al-Lughah wa Manâhij al-Bahts al-Lughawi ( 2001) by Nur al-Huda Lusyan, Manhaj al-Bahts al-Lughawi (2002) by Sulaiman Yaqut, and Manâhij al-Bahts fi al-Lughah wa al-Adab (2014) by Abdullah al-Sulami and Mukhtar al-Ghauts. Those masterpieces become intellectual assets that are valuable in guiding and dynamizing the research on Arabic, both its pedagogical and literary aspects.

Theoretically, research methodology of Arabic language is actually a "networking" research instrument that can accommodate various disciplines, such as' ilm al-Lughah (linguistics), fiqh al-lughah, 'ilm al-nafs (psychology),' ilm al-tarbiyah, and al-'ulûm al-'Arabiyyah (nahwu, sharaf, balâghah, etc.), even 'ilm al-Ihshâ' (statistics) and 'ilm al-manthiq (logic). When the researchers of Arabic would develop a method named "Effective Quran Reading and Writing Method" for Children or beginners (al-mubtadiûn), then they must acquaint the characteristics of the Arabic letters, makhāri al-hurûf, the purpose and structure of programs that is taught, and developmental psychology or educational psychology. In addition, dirasah taqâbuliyyah $^{12}$ (contrastive study) between the makhāri al-hurûf in Arabic and Indonesian is also necessary, so the similarities and differences are acquainted well. In fact, it is possible for the researcher to use the experimental method (manhaj tajrîbî) by conducting trials and evaluating the results. When the factors that cause errors in Arabic are known, both in Insya 'and in the Tarjamah Indun'siyyah-'Arabiyyah, It is necessary to do research on the variety of language errors using the tahlîl al-akhthấ ${ }^{\prime 13}$ (error analysis). Thus, the Arabic research methodology does not stand alone, but it is in a cross-scientific "world of methodology" that is varied, synergistic, and in need.

History proves that research of Arabic was initially carried out in the interest of "serving" the need for understanding towards Islamic teachings. After many people 'ajam (nonArab) converted to Islam, both in Africa such as Egypt, Sudan, al-Jazair, Libya, Morocco and Tunisia, and Asia such as Iran, Iraq, Azerbaijan, Arabic became increasingly significance to be studied as the instrument for understanding the sources of Islamic teachings. According to a history, 'Alî ibn Abî Thâlib (600-661 AD) was a caliph who initiated the need for the arrangement of Arabic rules. Then He instructed Abû al-Aswad al-Du'alî (16 sH-69 H) to codify what was outlined by Ali, as al-kalimat (word) can be divided into three: ism, fi'l and harf ${ }^{14}$. Starting from "budding the classification of words" (at-taqsîm ats-tsulâtsî), the research of language development is developed, then produced results in the form of science of nahwu, sharaf, balâghah, 'ilm ad-dalâlah (semantics) and so on.

The research of Nahwu is a research that is supported by the teachings of Islam - which greatly respects to the development of science and positions scientists ('ulama) to the highest or dignity (QS. Fâthir [35]: 28 and al-Mujâdilah, [58]: 11) - and also by Al-Quran which is derived in Arabic. It is 'Alî ibn Abî Thâlib $(40 \mathrm{H})$ best friend of the

${ }^{12}$ Look up to Robert Lado, "Dharuratal-Muqâranah al-Muntadhimah li al-Lughât wa al-Tsaqâfât" in Mahmûd Ismâ'îl Shînî, al-Taqâbul al-Lughawî wa Tahlîl al-Akhthâ', (Riyâdh: Jâmi'ah al-Malik Sa'ûd, 1982), p. 3.

${ }^{13}$ Mahmûd Ismâ'îl Shînî, at-Taqâbul al-Lughawî.., p. 3.

${ }^{14}$ Look up to Rihâb Khudhar 'Akkâwi, Mawsû'ah 'Abâqirah al-Islâm fi al-Nahwi, wa al-Lughah wa al-Fiqh, Vol. III, (Beirut: Dâr al-Fikr al-'Arabî, 1993), $1^{\text {st }}$ edition, p. 9. 
Prophet Muhammad SAW, who instructed Abu al-Aswad al-Du'alîî (16 sH-69 H) to conduct research of Arabic grammar because he saw many 'non-Arab' people who made mistakes (lahn) in reciting Al-Quran ${ }^{16}$, so that language error is feared to jeopardize the authenticity and originality of Al-Quran ${ }^{17}$.

C. Arabic language research and learning is inseparable from the "eagerness" of understanding the Islamic teachings. Therefore, religious motivation is a vital element that moves Muslims or educational institutions to study and explore Arabic, even though the motivation still needs to be strengthened by "academic-scientific motivation". The facts show that the main purpose of Arabic language education at various Islamic education institutions, starting from the basic to higher level of education, seems to be more oriented towards understanding of the sources of Arabiclanguage Islamic teachings (for passive proficiency), than for other interests, such as active verbal communication, diplomatic interests, politics, economy, trade, culture and so on.

Research and writing of nahwu books after Sîbawaih (d. 180 H) tends not to produce "new creativity", because the works of the nuhât tend to be fixed on al-Kitâb by Sîbawaih in the form of comments, syarah, summaries, and so on. In addition, according to Amin al-Khil (1885-1966), nahwu (read: thought of nahwu) that was influenced by Greek philosophy. The nuhas tend to treat the study of nahwu with a philosophical approach. As proof, they understand language as a logical activity which determined by logical reasoning, so nahwu becomes a pure logic pattern. The expression that "nahwu is an analogy (qiyas)", according to al-Khil, it is the influence of philosophy ${ }^{18}$. Nahwu is philosophical in nature - which emphasizes the excessive and non-functional i'râb ${ }^{19}$ and ta'lîl - Then, it becomes one of the factors of "the obstacle" in learning Arabic, especially nahwu and sharaf.

If it is associated with the interests of developing Arabic Language Education (PBA), then there are several trends in language research according to the scope of the existing linguistic fields (phonology, morphology, syntax, lexicology, lexicography, semantics, etc.), can be mapped as: 1) Constructive research (al-dirâsah altaqâbuliyyah), for example "constructive analysis between dhamîr (the pronouns) in Arabic and Indonesian"; (2) Error analysis research (tahlîl al-akhthâ'), for example: "analysis of errors in the use of the number of ismiyyah (nominal sentences) in insyâ (composition) and lecturing among Arabic Language Education Study Programs (PBA) students at the Faculty of Science Tarbiyah and Teacher Training (FITK) and Tarjamah Study Program at the Faculty of Adab and Humanities ";(3) Psycholinguistic research, for example: "The Influence of Interest in Learning Arabic towards Speaking Skills"; (4)

15 Rihâb Khudhar 'Akkâwi, Mawsû'ah 'Abâqirat al-Islâm, vol. III, (Beirût: Dâr al-Fikr al-'Arabî, 1993), ( $1^{\text {sted }}$, p.13-17.

${ }^{16}$ Rihâb Khudhar 'Akkâwi, Mawsû'ah ..., p. 9.

${ }^{17}$ Look up to Ibrâhîm as-Sâmarrâ'î, Min Asâlîb al-Qur'ân, (Beirût: Muassasah al-Risâlah, 1983), p. 6-10.

18 Amîn al-Khûlî, Manâhij Tajdîd fi al-Nahwwi wa al-Balâghah wa al-Tafsîr wa al-Adab, (Kairo: al-Haiah alMishriyyah al-`Âmmah li al-Kitâb, 1995), p. 55-56.

${ }^{19}$ Look up in Tammâm Hassân, Maqâlât fi al-Lughah wa al-Adab, Jilid I, (Kairo: 'Âlam al-Kutub, 2006), p. 135. 
Sociolinguistic research, for example: "The Influence of Mother Tongue towards Language Thinking in Insyâ 'among Arabic Language Education Study Programs (PBA) Students "; (5) Technolinguistic research, for example: "The Effectiveness of The Use of Language Laboratories in Istimâ 'and Kalâm Learning Towards Students of The Darun Najah Ulujami Islamic Boarding School in South Jakarta" (6) Lexicological research, for example: "Ibn Manzhûr method (630-711 H) Lisân al-'Arab Dictionary; (7) Arabic learning research, for example: "The Relationship Between Student Education Background and The Effectiveness of Arabic Learning in State Islamic University", or "Effectiveness of Direct Methods And Audio-Visual Methods in Learning Speaking Skills towards Arabic Language Education Study Programs (PBA) students".

\section{The Innovation of Arabic Learning}

In the study of applied linguistics ('ilm al-lughah at-Tathbîqî), Arabic learning is one form of linguistic application in the field of language learning. Therefore, several linguistic studies are synergized with psychology, sociology, neurology, educational sciences, etc., Thus, it produces psycholinguistics ('ilm al-lughah an-nafsî), sociolinguistics (' ilm al-lughah al-ijtimâ'i), neurolinguistics ('ilm al-lughah al-'ashabî). Psycholinguistics and sociolinguistics are closely related to Arabic learning.

The emergence of applied linguistics (ilm al-Lughah at-Tathbîqî) in 1946 in the journal Language Learning: The Journal of Applied Linguistics increasingly strengthened the importance of linguistic applications in language learning. Therefore, the use of the term for applied linguistics has created controversy. Mackey termed Language Didactics ('Ilm Ta'lîm al-Lughah); Spolsky proposes Educational Linguistics ('Ilm al-Lughah at-Ta'lîmî), and Wilkins offers Linguistics in Language Teaching (adDisârah al-IIlmiyyah li Ta'lîm al-Lughah al-Ajnabiyyah). Thus, it was agreed because it was not only related to language learning, but also other fields, the term used was applied linguistics ('ilm al-lughah at-Tathbîqî), with a focal point in language learning, both for the speakers themselves and for non-speakers . This discipline, according to Abduh ar-Rajihi, has two main characteristics, namely: mi ilmi (scientific) and ta'lîmî (educational) ${ }^{20}$.

As a product of linguistic thoughts (study and development), Arabic learning is definitely inseparable from learning theories, language theories, and psychological theories. When they want to teach Arabic to students, there are at least 5 questions that need to be asked and the answers clearly explained. First, what is the purpose of Arabic learning? If the purpose is clear, for example, learners are proficient in oral communication (mahârah kalam) in Arabic, and then the second question is what material that is suitable for that purpose? Third, Who are the Arabic language learners (children, adolescents, adults; elementary graduated, junior high, senior high or students, or the general public)? If the learner's identity and teaching material, then fourth, how to teach it (what method is in accordance with the objectives, learners, and

${ }^{20}$ look up in 'Abduh ar-Rajihi, 'Ilm al-Lughah at-Tathbîqi wa Ta'lîm al-'Arabiyah, (Alexandria: Dâr alMa’rifah al-Jâmi’iyyah, 1995), p. 8-12 
teaching materials prepared)? Fifth, what kind of media and learning environment in teaching and learning activity which need to be designed and developed?

And all this time, it has been assumed that ideal language learning and teaching (efficient and effective) requires the use of methods and media that enable students to achieve the goals. This assumption is not entirely wrong, but dependence on methods and media is not the main determinant of the success of teaching and learning of Arabic. In this digital era, many things change and require the teachers to be proactive, creative, and innovative in searching and finding the right strategies and approaches, in accordance with the objectives of learning Arabic and the needs of students. The post-method era was marked by the abandonment of "method arguments" in determining language learning strategies. Language teachers in this case are required to be able to find effective strategies and techniques in enriching the teaching process $^{21}$.

Along with the development and progress of science and technology in the field of informatics, Arabic learning also needs to be supported and developed based on ICT (information and communication of technology). With the implementation of ICT on campus or other educational institutions, the academic community (especially lecturers and students) certainly must be given internet access or can be connected to the internet anywhere and anytime. In other words, lecturers and students must be dynamic. The application and utilization of ICT in the world of education requires the availability of supporting facilities and infrastructure, such as laptop and an adequate multipurpose internet network.

ICT-based language learning of Arabic is basically an Arabic language learning model which based on the availability of access that makes it easier for lecturers / teachers and students / students to connect with official sites, as well as other sites to explore and find information that has educational value. The method, among others, is the presence of wireless fidelity (Wi-Fi) service facilities in the campus area. With free and fast internet access, learning Arabic in classrooms will become more innovative. The lecturer can show and enrich the lecture material by opening websites that are directly related to Arabic, such as: isesco website, diwanalarab, alukah, lisaniyat, awu-dam, and so on. If the information (news) from various newspapers in the Middle East is needed, lecturers or students can easily access the newspapers alriyâdh, alahram, ukâz, al-syarq al-awsath, al-manâr, almadînah, and so on.

In its development, ICT-based language learning of Arabic must be accompanied by the changes in the mindset or paradigm of learning of lecturers and students, as well as supported by ICT skills. In his book, Effective Teaching, Evidence and Practice, Daniel Muijs and David Reynolds explained some things about ICT skills. How can ICT help the academic community learn well, including Arabic learning?

${ }^{21}$ Arda Arikan, "Postmethod Condition and Its Implication for Language Teacher Education", in Journal of Language and Linguistic Studies, Vol. 2, No. 1, April 2006, p. 2.

Look up in Muhbib Abdul Wahab, "Pembelajaran Bahasa Arab di Era Posmetode", in Arabiyat: Jurnal Pendidikan Bahasa Arab dan Kebahasaaraban, Vol.2, No.1, Juni 2015, p. 59-74. 
First, presenting information (taqdîm al-ma'lûmât). ICT has a very extraordinary ability to convey information. Encyclopedias with a number of volumes can be stored on the hard disk. Even now Google-earth has been existed that can show us the entire region on our earth from the impressive results of aerial photography. By opening and asking for help from Google, our data and information will be easily obtained. For the example, If we want to get the recording of the Dr. Yusuf alQaradawi, Google with a super fast data and information search engine can show what we expect. If we want to find funny pictures for intermezzo - so that learning activity is more fascinating - Google presents it to us fast.

Second, the quick and automatic completion of the tasks routine. Our routine tasks can be completed by using a computer quickly and automatically. Want to make a graph, make animated exposure, and so on, can easily be done with the help of a computer. In this context, I consider it important that ICT can be optimized for research-based Arabic learning.

Third, assessing and handling information. With computers that connected to the internet, we can easily obtain and send information easily and quickly. Through the internet network, we have a website that is able to reach the edge of any world. Our children can easily chat or chat with friends. Through e-mail, we can exchange information, send writings / papers, pictures, etc. quickly, precisely, and practically.

According to the author, the innovation of ICT-based learning of Arabic can be developed and applied not only in mahârât lughawiyyah learning (istimâ 'kalâm, qirâ'ah, and kitâbah), but also other linguistic materials: qawâ'id, balâghah, literature, linguistics, and so forth. In practice, teaching materials that will be lectured to students need to be designed in such a way that the materials can be accessed or learned directly from the website or blog that has been provided. By using a powerpoint application, language games, teaching materials can be made by lecturers so that it is easier for students to learn. At the same time, if in the learning model (lecture) the method of seminar / discussion is used, then students can be assigned to present their papers in the form of powerpoints, so that they are accustomed to presenting their thoughts well and effectively.

In ICT-based learning of Arabic, the classroom atmosphere is ideally designed to be more active, dynamic, interactive and fun (joyful learning). Therefore, lecturers must be creative in utilizing various sources (multi-resources) that enable students to learn by optimizing multiple intelligence. Thus, the output (outcome) of learning becomes more memorable, optimal, and effective.

Then, through ICT, traditional learning models that consider lecturers / teachers as the main source of information must be changed and replaced with modern learning models that optimize the use of various sources, various approaches, various models, and creative and inspirational Arabic-language exercises. Elements of al'ab lughawiyyah (language games) also need to explore the process of learning Arabic. With ICT, we hope and must be able to prove that the image of Arabic learning that has been suggested to be difficult can be changed to be easy, fun, and exciting. Of course, this change of image requires a mental change and high creativity, especially from 
educators. Due to that, the education profession must be more appreciated and given adequate compensation.

Hence, innovation, trends, and new orientations (ittijâhât hadîtsah) in Arabic learning in the digital era today need to be formulated in such a way that Arabic learners can achieve the expected goals efficiently and effectively 22.

\section{E. Digitizing and standardization of Arabic Learning}

Arabic Learning in the digital era today needs to utilize sophisticated information and communication technology to support and increase its effectiveness. Therefore, Arabic learning must change its orientation from the manual and the traditional to the digital and edutainment, it has to combine the aspects of education and consolation. Language games (al'âb lughawiyyah) in various elements of language (ashwât, mufradât and tarâkib) and four language skills (istimâ ', kalâm, qirâ'ah, and kitâbah) need to be developed based on ICT.

In this context, the synergic cooperation between Arabic language experts and ICT experts is needed in designing and developing various interesting and fun multimedia and Arabic language learning applications. The media and Arabic learning applications that have nuances of edutainment (entertaining, joyful, and fun education) can be enrichment for the Arabic learning process in the classroom and at the same time can be a motivating medium for the formation of an Arabic-speaking environment in our educational institutions. According to the theory of language games, Arabic learning will be more interesting, challenging, entertaining, and refreshing the learners if there are any various educational games, because games - including language games according to Jean Piaget and Vygotsky are the foundations of growth and mentalintellectual development, also the thoughts and needs of the learner ${ }^{23}$.

According to the author, digitizing of Arabic learning can be done by designing learning resources (books, articles, newspapers, magazines, etc.) that are realized in the form of e-learning (website-based) or at least in the form of CD programs that contain various teaching materials and sources of learning Arabic. The actual existence of maktabah syâmilah and other interactive learning program CDs are expected to help accelerate and process Arabic language learning products that are efficient and effective. The problem then is how to develop the interest in reading, interest in research, interest in writing and effective discussion among students, so that the existence of multimedia learning actually removes the substance from learning Arabic itself.

Therefore, the author proposes the need to make the standardization of Arabic language learning at the national level to be more concrete and operational. The

${ }^{22}$ Look up in Munif Hudhair al-Dhawi, an-Nazhariyyah al-Binâiyyah wa Tathbîqatuha fi Tadrîs al-Lughah al'Arabiyyah, (Riyadh: Maktabah al-Malik Fahd al-Wathaniyyah, 2013), $1^{\text {st }}$ edition, p. 33-35.

${ }^{23}$ Muhammad 'Ali as-Shuwairiki, al-Al'ab al-Lughawiyyah wa Dauruhâ fi Tanmiyat Maharat al-Lughah al'Arabiyyah, ('Amman: Maktabah al-Thalabah al-Jami'iyyah, 2005), p. 13. 
standardization can be partially adopted from the National Education Standard which consists of 8 standards (Competence of graduates, educators and education staff, content, process, infrastructure, management, financing, assessment). In addition to these 8 standards, according to the author, there are still standardization of textbook writing, standardization of language research, standardization of Arabic-Indonesian dictionaries and vice versa, standardization of the formation of the bî'ah lughawiyyah, standardization of Arabic-Indonesian translation and otherwise, and so on. The standardization can be carried out by IMLA or other professional and scientific associations that are competent in their fields. This is an "Arabic Project of Future" that needs to be appreciated and supported by many parties, so that the prospect of Arabic learning in Indonesia in the future is more exciting, fascinating, and fun.

\section{Conclusion}

From the study above, it can be concluded that linguistic thoughts and learning of Arabic in Indonesia need to be innovated in three levels, namely the study and development of Arabic linguistics, contextualization of Arabic research methodology, and standardization of ICT-based learning and research of Arabic. Innovation and creativity in Arabic learning are not only intended to optimize learning processes and products, but to improve the quality of human resources (educators, developers, and practitioners of Arabic language).

The solutions to the problems of Arabic learning can be found through Arabic linguistic research and study in an in-depth, comprehensive and cross-disciplinary of science, besides through academic and scientific community discussions among lecturers, researchers, and Arabic activists.

Therefore, it is suggested the need to establish Arabic linguistic towards the society in Indonesia which periodically conducts seminars, discussions, conferences and workshops related to the development of Arabic linguistic thoughts in Indonesia. Various efforts to standardize the studies, research, and development of Arabic linguistics in Indonesia also need serious attention, for example standardization of the Arabic-Indonesian dictionary and vice versa, standardization and digitalization of interactive CDs for Arabic learning, translation, standardization and digitalization of skills learning models, the elements of Arabic, and so on.

\section{References}

'Abduh al-Hilwu and Bahzad Jabir. Al-Wafi Fi TâRîkh Al- 'Ulûm 'inda Al-'Arab.

'Abduh ar-Rajihi. 'Ilm Al-Lughah at-Tathbîqi Wa Ta'Lîm Al- 'Arabiyah. Dâr al-Ma'rifah al-Jâmi'iyyah, 1995.

Ahmad SH. Al-Khatib. Mu’jam Al-Mushthalahât Al- 'Ilmiyyah Wa Al-Fanniyah Wa Al-Handasiyyah. 1991.

Alan Clark. Nahwa Uslûb Jadîd Fi Ta'lîm Al-Lughah Al-'Arabiyyah.

Amîn al-Khûlî. ManâHij Tajdîd Fi Al-Nahwi Wa Al-BalâGhah Wa Al-Tafsîr Wa Al-Adab. al-Haiah al-Mishriyyah al'Âmmah li al-Kitâb, 1995.

Arda Arikan. "Postmethod Condition and Its Implication for Language Teacher Education." Journal of Language and Linguistic Studies, vol. Vol. 2,. No. 1, April, 2006, 
Hassân, Tammâm. Ijtihâdât Lughawiyyah. 2007.

Henry Guntur Tarigan. Pengajaran Pragmatik. Angkasa, 2009.

Ibrâhîm as-Sâmarrâ'î. Min AsâLîb Al-Qur'âN. Muassasah al-Risâlah, 1983.

Jose Miguel Puerta Vilchez. Reading the Alhambra: A Visual Guide to the Alhambra through Its Inscripstion. 2010.

Mahmud Ahmad Nahlah. Âfâq Jadîdah Fi Al-Bahts Al-Lughawî. Dâr al-Ma'rifah al-Jami’iyyah, 2002.

Mahmûd Ismâ'îl Shînî. Al-TaqâBul Al-Lughawî Wa Tahlîl Al-Akhthâ'. Jâmi’ah al-Malik Sa'ûd, 1982.

Muhammad 'Ali as-Shuwairiki. Al-Al'ab Al-Lughawiyyah Wa Dauruhâ Fi Tanmiyat Maharat Al-Lughah Al'Arabiyyah. Maktabah al-Thalabah al-Jami'iyyah, 2005.

Muhbib Abdul Wahab. , Pemikiran Linguistik Tammâm Hassân Dalam Pembelajaran Bahasa Arab. 2009.

---. "Pembelajaran Bahasa Arab Di Era Posmetode." Arabiyat: Jurnal Pendidikan Bahasa Arab Dan Kebahasaaraban, vol. Vol.2, no. No.1, Juni 2015, 2015, pp. 59-74.

---. "Peran Bahasa Arab Dalam Pengembangan Ilmu Dan Peradaban Islam.” Arabiyat: Jurnal Pendidikan Bahasa Arab Dan Kebahasaaraban, vol. Vol. I, no. No. 1, Juni 2014, 2014, pp. 1-20.

Munif Hudhair al-Dhawi. An-Nazhariyyah Al-Binâlyyah Wa Tathbîqatuha Fi Tadrîs Al-Lughah Al- 'Arabiyyah. Maktabah al-Malik Fahd al-Wathaniyyah, 2013.

Rihâb Khudhar 'Akkâwi. Mawsû'ah 'AbâQirah Al-Islâm Fi Al-Nahwi, Wa Al-Lughah Wa Al-Fiqh. Dâr al-Fikr al'Arabî, 1993.

Robert Lado. Dharuratal-MuqâRanah Al-Muntadhimah Li Al-Lughât Wa Al-TsaqâfâT.

Sa'id bin Ali al-Qahthani, et. al. A'mâl Mu'tamar IttijâHat Hadîtsah Fi Ta'lîm Al-Lughah Al-'Arabiyyah Lughah TsâNiyah. 2014.

Tammâm Hassân. Al-Fikr Al-Lughawî Al-Jadîd. 2011.

---. Maqâlât Fi Al-Lughah Wa Al-Adab. 'Âlam al-Kutub, 2006.

Victoria Neufeldt et.al. Webster's New World Dictionary. 1988. 